\title{
SMARTPHONE AND APP USAGE AMONG COLLEGE STUDENTS: USING SMARTPHONES EFFECTIVELY FOR SOCIAL AND EDUCATIONAL NEEDS
}

\author{
Gayle R. Jesse, Liberty University, gjesse@liberty.edu
}

\begin{abstract}
Smartphones and the applications (apps) that can be downloaded to smartphones are inventions that keep individuals connected to society, especially college students. This paper discusses the relationships between smartphone usage and the effects of smartphones on students' social lives, education lives, and physical activity levels. Furthermore, the paper explores student preferences on the most and the least useful smartphone apps. There are four main purposes of this study: determine the preferred smartphone operating system among college aged students, which apps college students use most and least, what primary app is used, and social media app usage. This study compared data collected via survey from 395 students at two academic institutions during the Spring 2013 semester. The explanatory study yielded four significant findings: 1. College aged students own an Android operating system; 2. Students have approximately 25 apps installed on their smartphones; 3 . The most and least useful apps are utility based and travel apps, respectively, and the most used are social media; and, 4. Students open their primary app six times a day with Facebook as the primary social media app. Overall, this research study informs the information systems (IS) community and educators because understanding how to connect to students helps IS educators engage them in the classroom. Smartphones and their apps are two technologies that can impact a student's education and psychological wellbeing.
\end{abstract}

Keywords: Cellphones, Smartphones, App Usage, Mobile Technology, Social Needs, College Students

\section{INTRODUCTION}

Unsurprisingly, Post (2011) found that $99.8 \%$ of college students own cellphones. College students feel cellphones, particularly smartphones, are an essential to survive. Today, many students primarily use smartphones for texting and running applications or apps. Thus, phones are rarely used to make actual phone calls. Moreover, the number of college students using their cellphones during class has increased over the last few years. According to Jesse (2013), $80 \%$ of students admit to texting at least once while in class. Furthermore, smartphone social media apps give users the ability to check social media sites anywhere at any time instead of having to utilize a more traditional computer. Peterson (2011) stated that apps are a portable way to stay connected via social media, and $97 \%$ of smartphone users use apps for social networking purposes. Because of this increase in usage, cellphone apps continually add new features such as location tagging and status updates to entice mobile users. Many students will share exactly where they have been or where they are going on social media and then tag their friends. While this level of sharing does not necessarily align with social media safety practices, many college students are continually using these app features. Additionally, game app usage is also widely accessed among the smartphone community. Laird (2012) conducted a study and reported that $55 \%$ of students use gaming apps either regularly or as a leisure activity on their smartphones. These multifunctional cellphones are used while waiting in line at the coffee shop, searching various topics on Google, keeping track of homework assignments, and staying connected to friends from school and at home. The increasing uses of smartphones and apps significantly affect students. This research paper will further explore the trends of smartphone and application usage among college students. Specifically, this study explored four objectives: preferred operating system, primary app used, most and least useful apps, and social media app usage. 


\section{Issues in Information Systems}

Volume 17, Issue IV, pp. 8-20, 2016

\section{LITERATURE REVIEW}

\section{Student Learning (Advantages and Disadvantages)}

Multiple studies have been conducted to examine the advantages and disadvantages of incorporating cellphones for improved student learning outcomes. Epstein (2013) researched a clinical practice and the inclusion of cellphones to more fully individualize a therapeutic process. The patients were analyzed using their cellphones and then plans were made to assist individuals with their behavior. According to Epstein (2013), mobile technology is the single most rapidly embraced technology in world history. Additionally, "cellphones are very convenient, easy to carry, and readily integrated into a user's routine and many people have their phone with them during all waking hours" Epstein (2013). Furthermore, a student with social anxiety could use a cellphone to practice a class speech by talking on their phone. Epstein's 2013 clinical study also found that app usage could possibly help improve completion of homework. Further findings were related to text messages. Epstein (2013) found that texting helped the participants to complete homework, enhanced therapeutic alliance, improved self-efficacy, and increased patients' overall positive feelings about themselves. Additionally, Elder's (2013) study explored college students' self-reported cellphone usage and beliefs, and further investigated the effects on student learning. Elder (2013) reported that $85 \%$ of university faculty and students both said cellphones were distracting, and $45 \%$ noticed that vibrating phones in the classroom were problematic. The study described ways cellphones function beyond just phone calls, and college students are now multitasking in classes by texting and listening to the professor's lecture simultaneously. Chen (2013) researched educational versus non educational app usage among college students. Chen's (2013) findings include: 58\% of the college students used their mobile devices for academic purposes, and freshmen and sophomores tended to use their mobile devices more for educational purposes than upperclassmen.

Baker's (2012) study was based on cellphone use and other electronic devices in the classroom. Baker (2012) found that $45 \%$ of students report spending more than four hours a day on their cellphones. Tulane's (2010) study asked students questions related to cellphones and their usage. The Tulane (2010) study found that the amount of text messages college students send and receive ranges from two to 25,543 a month with an average of 1,960 texts. Furthermore, cellphone usage is changing how people act in public; texting is used to fill time, and the individuals partaking in this do not think their actions are unacceptable.

Even though college students' app usage is high, the usage is not necessarily driving negative consequences. Nahorniak (2012) explained how professors and students created an app for a finance class to better experience stock trading. Nahorniak (2012) concluded that the app was beneficial to the students. The app connected the theories and economic laws being taught in classes by putting students in a simulated situation, which allowed students to develop a better understanding of the workings of financial markets and the foundations of economic theory. eCycle (2012) also discussed the advantages and disadvantages of apps as learning and teaching tools. Smartphone apps allow college students to access information quickly, thus increasing their academic performance. eCycle (2012) further states that smartphones can help students create flash cards, prepare for presentations, instantly get answers to questions, record films and voice, and then send the recordings to their computer. Disadvantages analyzed by eCycle (2012) are cost, device size, battery life, and usability (small keypad making it hard to type). eCycle (2012) explained why administrators should reconsider allowing students to use their phones in class because the cellphones can be quite usable in an educational setting, especially since laptops are bigger and less portable. Additionally, cellphones could potentially be a helpful teaching tool in the classroom. One example is the Dropbox app. Students use the Dropbox App for file sharing within the classroom. Teachers can also use Dropbox to distribute handouts quicker and use less paper resources. Dropbox works on personal computers (PCs). Therefore, when logged into a PC Dropbox account, the files on a phone's Dropbox account can also be seen on the PC Dropbox account. A second example is Evernote. Students can use this app to review lecture notes after class. .Finally, eCycle (2012) stated that students could use their cellphone cameras to take pictures of the black/white board or to record professors' lectures during class for later review.

\section{App Usage versus Smartphone Web Browser Usage}

Student accessibility to information has been an area of growing research interest in academia and industry. Tally (2012) conducted a study comparing student app preference to smartphone web browsers, and found students will 


\section{Issues in Information Systems \\ Volume 17, Issue IV, pp. 8-20, 2016}

more frequently utilize a weather app instead of using a web browser. These results suggest that students want to use apps over a regular web browser. Furthermore, $85 \%$ of students responded that they preferred the app versus the web in Tally's (2012) study. Bowen (2012) also determined that students spend more time utilizing mobile apps than smartphone browsers and noted, "overall, students reported spending more time using mobile apps, and as students become more advanced in their use of smartphones, the gap widens - the amount of time spent using mobile apps increases, while the amount of time spent using a smartphone browser remains relatively consistent". Due to the increase in app usage, EMarketer (2012) researched which apps college students used the most and concluded that most smartphone owners use their apps primarily for communication and social media. More specifically, the EMarketer (2012) results indicated that $21 \%$ of college students use their smartphones for communication, 19\% use social networking apps, and Facebook was the most commonly used app.

\section{Nomophobia - Psychological Effects of Cellphones}

Multiple psychological effects emerge from cellphone ownership and usage. Hingorani's (n.d) study examined how smartphones support students' lives and the issue of "nomophobia" (or no mobile phone phobia), which is the fear of being without a mobile phone. Results showed that students do not utilize their phones for just texting and calling; smartphones are used for social media, music, recording, gaming, and streaming. Hingorani (n.d) stated that students feel they can multitask when using smartphones in the classroom and professors should not object to their usage. Additionally, Hingorani (n.d) stated that students use their cellphones to feel connected with others, and without that connection students' lives would be negatively affected. Hingorani's (n.d) study also demonstrated that many students' may suffer from "nomophobia" and the condition impacts their lives. Beaver's (2010) study on cellphone use required a sample of college students to go without cellphone use for two days, and the results showed the students experienced great distress.

Berger's (2013) study showed that students who engage cellphone usage more heavily both in class and out of class earn lower grades than peers who use their phones less. Berger's (2013) survey sample consisted of 500 undergraduate students with a range of majors. The findings concluded: students who used cellphones more had lower grades and higher anxiety and were less happy than students who don't use their cellphones as often (Berger 2013). In addition, Smith (2013) determined that students who use their phones more frequently had a lower grade point average (GPA) and higher anxiety. One student in Smith's (2013) survey stated: "The social network sometimes just makes me feel a little bit tied to my phone. It makes me feel like I have another obligation in my life that I have to stick with. Sometimes the cellphone just makes me feel like it is a whole new world of obligation that I have because anybody can get a hold of me anytime by just thinking about me. If my mom wanted to give me a call right now and just talk for a second, she could. And if I did not call her back by the end of the day, she would get worried. It creates a bit of anxiety and it is kind of annoying sometimes." The majority of Smith's (2013) respondents noted a dependence on their phones because they experienced anxiety when they had to go without it for a certain period of time, and the respondents felt obligated to have cellphones on their person at all times.

Martin (n.d.) conducted a study to determine if cellphone usage affects students' concentration levels in class and the amount of information they actually process with the distraction of cellphones. Students responded that cellphone usage in class affects their concentration and the information they receive, but they feel more comfortable when they can check their cellphones in class. Martin (n.d) also found that the two most commonly used cellphone features were texting and the clock. The study further concluded that $45 \%$ of students frequently hide their cellphone usage in class, and $41 \%$ of students are ready to concentrate after they check their phones during class. To further support these findings, Weimer (2014) also explored the ways students are distracted by their cellphones. According to Weimer (2014), students are not able to effectively multitask, and cellphones are a distraction in the classroom. "Students who use their mobile phones during class lectures tend to write down less information, recall less information, and perform worse on a multiple choice test than those students who abstain from using their mobile phones during class" (Weimer 2014). Furthermore, Weimer (2014) examined students' perceptions on completing basic tasks, such as eating and driving, while still using their phones. To conclude, Weimer (2014) provided suggestions on ways to encourage students to put away their phones and pay attention in class, but ultimately noted there really is not an effective way to get someone to stop using their cellphones during class time. 


\section{Relationships}

Interpersonal relationships have long been affected by technological developments. Tulane (2010) states that texting can be used for numerous communication purposes and many text messages are sent to maintain interpersonal relationships. Beaver (2010) supported these findings by exploring how cellphones impact relationships. Specifically, African American respondents were bothered more by their partners use of cellphones than Caucasian respondents. Beaver (2010) also noted that many individuals view cellphones as a safety device for parents and children because parents typically fear for their child's physical safety.

\section{Fitness}

Fitness app usage has grown by $87 \%$ compared to other apps; however, the predominant app users are women ages 25-54, who are not typical college students (Russell, 2014). Thomas (2013) discussed the relationship between cellphone usage and fitness in college students. Thomas (2013) hypothesized students would use their cellphones during physical activity because they are more portable than televisions, but his findings indicated an opposite response. Thomas (2013) stated, "despite the phone's mobility, high use contributed to a sedentary lifestyle for some subjects." Additional findings indicated that students who had very high cellphone usage also had low cardiorespiratory fitness, and the students who were the least fit would spend most of their time using their cellphones (Thomas 2013). Thomas (2013) concluded, " [the] findings suggest that cellphone use may be able to gauge a person's risk for a multitude of health issues related to an inactive lifestyle." These findings connect to Hamilton's (2013) discussion of high cellphone usage among college students leading to poor fitness levels and a sedentary lifestyle. Students who spent up to 14 hours on their cellphones were less fit than those who averaged 90 minutes of cellphone use daily. Furthermore, students who spent a large amount of time on phones often spent their leisure time playing video games and watching movies. Hamilton (2013) also determined that students were inclined to pass up going outside or participating in physical activity, and instead would utilize a social media site. Finally, students who used their phones less agreed that they were more motivated to do physical activity and contacted physically active friends to do things together.

\section{Race and Sex Usage Differences}

Myriad findings have emerged based on demographic factors such as race and gender. Beaver's (2010) analysis indicated Asian students tend to use their devices to complete assignments more frequently than other groups; male students use apps for academic purposes more than females; and, age has a small but significant impact on cellphone use. This study also found that Caucasian students were more likely to regularly use their cellphones than African American students. Additionally, Beaver's (2010) study reported that African American students were twice as likely as Caucasian students to be annoyed by their partner's use of a cellphone when the two were together.

Tulane (2010) explored the difference in cellphone usage between males and females. The study reported that females average more texts per day than males; females use texting as a form of relaxation and escape more than males; and, females are more likely to use texting to connect with other individuals than males. However, Beaver's (2010) study found that females had higher cellphone use than males.

\section{METHODOLOGY}

\section{Research Design}

"This explanatory study was designed utilizing quantitative methods. Conducting this quantitative study involved administering a survey in three phases. The first phase consisted of developing a survey instrument, which consisted of developing questions based upon the gap in the literature and researcher questions. The second phase included testing the survey with one Thiel College student. Only one student was used to assist the research with clear wording of survey questions and to determine the time needed to complete the survey. Finally, the third phase entailed distribution to traditional college aged Thiel College and Robert Morris University students utilizing 
SurveyMonkey. The survey research maintained an objective approach. Four software products were used: Moodle Learning Management System, e-mail, SurveyMonkey, and Microsoft Excel”(Jesse, 2013).

\section{Participants}

This study involved two target populations: Thiel College (TC) and Robert Morris University (RMU). Both institutions were used as a convenience sample. The survey was distributed to the entire Thiel College population, while only students in the School of Communications and Information Systems at Robert Morris University were invited to complete the survey. At RMU, the School of Communications and Information Systems consists of the following five departments: Communications, Computer and Information Systems, English Studies and Communications Skills, Organizational Leadership, and Media Arts. Thiel College (Greenville, PA) and Robert Morris University (Moon Township, PA) are both located in western Pennsylvania approximately 70 miles apart. The participation statistics are listed in the Appendices, which provide the Spring 2013 enrollment statistics for both schools. The response rate was approximately $30 \%$ at TC and $11 \%$ at RMU, averaging a $21 \%$ response rate.

\section{Survey Distribution}

Survey participants volunteered to respond by clicking on a SurveyMonkey link distributed via three e-mails sent by the researchers (professor recruitment) at both institutions. Eligible participants were at least 18 years old and enrolled at Thiel College or Robert Morris University. Engaging participants from the entire Thiel College population reflected a true representation of the college's student body across multiple majors and their views on smartphones and apps. However, due to time constraints, only students in the School of Communications and Information Systems at Robert Morris University were invited to complete the survey.

\section{Survey Instrument}

"The survey was conducted via surveymonkey.com link. The survey instrument developed for this study was derived from multiple sources and included both validated (surveymonkey.com) and non-validated questions (author created). The initial survey was divided into the following six sections: Consent Form; Demographic Information; Social Media; Smartphones; E-Readers \& E-Textbooks; Thank you" (Jesse, 2013). While the survey instrument covered three main sections, Social Media, Smartphones, and E-Readers \& E-Textbooks, only results about Smartphones are considered in this paper.

\section{RESEARCH QUESTIONS}

A significant amount of research exists on the effects of cellphone use among college students. The proliferation and functionality of cellphones has caused a dramatic shift in how society uses cellphones. As a technologically driven society, the shift has gone from occasional cellphone use to constant cellphone use. This shift can be attributed to the fact that individuals have transitioned from using a cellphone without Internet functionality to a smartphone with an Internet connection. Due to the many smartphone capabilities, the diffusion and increased usage of smartphones grew exponentially when compared to previous technologies. Therefore, this study had four objectives: determine the preferred operating system, primary app used, most and least useful apps, and social media app usage. The information and research presented in the Literature Review section, in conjunction with the administration of a survey described in the Methodology section, provided insights to answer seven Research Questions (RQ).

The purpose of this study was to explore app usage among college students. The seven research questions to be answered were:

RQ1: Do college students own an Android or Apple operating system smartphone?

RQ2: How many apps are typically installed on college students' cellphones? 
RQ3: What apps are most useful to college students?

RQ4: What apps are least useful to college students?

RQ5: What apps do college students use the most?

RQ6: How often do college students enter into/use their primary app in a day?

RQ7: What social media app is primarily used among college students?

\section{DATA ANALYSIS}

Microsoft Excel software was utilized to calculate the percentage based statistics reported in this study; all results exclude the system missing responses and $(\mathrm{N}=\mathrm{XXX})$ represents the number of responses. Appendix A contains the demographic statistics of age, gender, race, grade point average (GPA) on a 4.0 scale, and college majors reported in 2013 from both Thiel College (TC) and Robert Morris University (RMU). The survey results in Appendix A are displayed in two ways: percentage for each school and average percentage between the two institutions. The average percentage between the two institutions was calculated by adding the TC and RMU percentages together, and then dividing the answer by two. The researcher determined that calculating the average percentage between the two institutions reflected the best overall statistical survey findings for the information systems community. Therefore, Tables 1-7 in Appendix A display the response percentages and average percentage between the two learning institutions.

\section{FINDINGS}

This study provides practical insights for the field of computer information systems by exploring college students' smartphone usage and the effects smartphones have on college students. As previously stated, the statistical survey findings were determined by calculating the average percentage between the institutions. The seven research questions in this exploratory study found the following statistics and some results were considered significant.

Objective 1: Owned Operating System

Finding: Students own the Android operating system.

Table 1. RQ1: Owned Operating System

\begin{tabular}{|l|l|}
\hline $52 \%$ & Own a smartphone with an Android OS \\
\hline $48 \%$ & Own a smartphone with an Apple iOS OS \\
\hline
\end{tabular}

Objective 2: Primary App Used

Finding: Students have approximately 25 apps installed on their smartphones.

Table 2. RQ2: Primary App Used

\begin{tabular}{|l|l|}
\hline 30 & Average number of apps installed \\
\hline 25 & Median number of apps installed \\
\hline
\end{tabular}

Objective 3: Most and Least Useful Apps

Finding: Students' most useful apps are Utility Apps. The students' least useful apps are Travel Apps. The most used apps are social media, and students use their primary app approximately six times per day.

Table 3. RQ3: Most Useful Apps

\begin{tabular}{|l|l|}
\hline $74.20 \%$ & $\begin{array}{l}\text { Utility apps (calculate, convert, } \\
\text { translate, etc.) }\end{array}$ \\
\hline $73.65 \%$ & Social networking apps (location check- \\
\hline
\end{tabular}




\begin{tabular}{|l|l|}
\hline & ins, friend status updates, etc.) \\
\hline $69.75 \%$ & $\begin{array}{l}\text { Weather apps (local forecasts, natural } \\
\text { disaster updates, etc.) }\end{array}$ \\
\hline
\end{tabular}

Table 4. RQ4: Least Useful Apps

\begin{tabular}{|l|l|}
\hline $57.35 \%$ & $\begin{array}{l}\text { Travel apps (airplane tickets, tourist } \\
\text { guides, public transportation info, etc.) }\end{array}$ \\
\hline $40.90 \%$ & $\begin{array}{l}\text { Sports apps (sports schedules, scores, } \\
\text { headlines, etc.) }\end{array}$ \\
\hline $36.50 \%$ & $\begin{array}{l}\text { Entertainment apps (movie trailers, } \\
\text { celebrity gossip, radio station guides, } \\
\text { etc.) }\end{array}$ \\
\hline
\end{tabular}

Table 5. RQ5: Apps Used the Most

\begin{tabular}{|l|l|}
\hline $47.25 \%$ & $\begin{array}{l}\text { Social Media (Twitter, Facebook, } \\
\text { Instagram, Pinterest) }\end{array}$ \\
\hline $14.57 \%$ & Mail \& Messaging \\
\hline $4.35 \%$ & Actual - RMU - Web Browser \\
\hline $7.25 \%$ & Actual - Theil - Games \\
\hline
\end{tabular}

Table 6. RQ6: Primary App Used Every Day

\begin{tabular}{|l|l|}
\hline 11 & Average times per day \\
\hline 6 & Median times per day \\
\hline
\end{tabular}

Objective 4: Determine Social Media App Usage

Significant Finding: Students chose Facebook as their primary social media app.

Table 7. RQ7: Most Useful Apps

\begin{tabular}{|l|l|}
\hline $82.95 \%$ & Facebook \\
\hline $62.25 \%$ & Twitter \\
\hline $29.15 \%$ & Pinterest \\
\hline $9.90 \%$ & None \\
\hline
\end{tabular}

Additional Findings: The following three additional findings are based on other Survey Questions (SQ) that the researcher asked, but were not considered an objective of this study.

Table 8. SQ18: Most Useful Apps

\begin{tabular}{|l|l|l|}
\hline RMU & $88 \%$ own a smartphone & $\begin{array}{l}100 \\
\text { responses }\end{array}$ \\
\hline Thiel & $81 \%$ own a smartphone & $\begin{array}{l}281 \\
\text { responses }\end{array}$ \\
\hline
\end{tabular}

Table 9. SQ25: Most Useful Apps

\begin{tabular}{|l|l|l|}
\hline RMU & $\begin{array}{l}60 \% \text { use social media on } \\
\text { smartphone during class }\end{array}$ & $\begin{array}{l}83 \\
\text { responses }\end{array}$ \\
\hline Thiel & $\begin{array}{l}67 \% \text { use social media on } \\
\text { smartphone during class }\end{array}$ & $\begin{array}{l}219 \\
\text { responses }\end{array}$ \\
\hline
\end{tabular}

Table 10. SQ26: Most Useful Apps

\begin{tabular}{|l|l|l|}
\hline RMU & $\begin{array}{l}77 \% \text { sent a text message } \\
\text { during class }\end{array}$ & $\begin{array}{l}95 \\
\text { responses }\end{array}$ \\
\hline Thiel & $\begin{array}{l}83 \% \text { sent a text message } \\
\text { during class }\end{array}$ & $\begin{array}{l}274 \\
\text { responses }\end{array}$ \\
\hline
\end{tabular}




\section{DISCUSSION}

RQ1: Do college students own an Android or Apple operating system smartphone? As a whole, the responses indicated that $52 \%$ of college students own a smartphone with an Android operating system and $48 \%$ iOS Apple operating system. When looking at data separately per institution, the results were reversed by approximately $10 \%$ with Thiel College students own an Apple's iOS smartphone, and Robert Morris students own an Android smartphone. However, this is a limitation to the study because of the different samples size from each institution. See Appendix A, Table 1.

RQ2: How many apps are typically installed on college students' cellphones? RQ2 found the average college student has 30 apps installed with a median number of apps being 25. See Appendix A, Table 2.

RQ3: What apps are most useful to college students? The surveys indicated that Utility apps are the most useful to college students. The second and third most useful apps are Social Networking and Weather apps, respectively. See Appendix A, Table 3.

RQ4: What apps are least useful to college students? The data gathered from the surveys indicated Travel apps to be the least useful apps to college students followed by Sports and Entertainment. See Appendix A, Table 4.

RQ5: What app do college students use the most? The researcher discovered that the average college student uses social media, mail, and messaging apps most. The next most useful app indicated a change: Thiel College students preferred game apps, and Robert Morris students used their web browsers. See Appendix A, Table 5.

RQ6: How often do college students enter into/use their primary app in a day? RQ6 found that college students, on average, enter into their primary app 11 times a day and the median was 6. See Appendix A, Table 6. A primary app is defined as an app that is used the most.

RQ7: What social media app is primarily used among college students? The data indicated Facebook was the primary social media app among college students followed by Twitter and Pinterest. See Appendix A, Table 7.

\section{LIMITATIONS}

Although this study had many limitations, only two major limitations are discussed in detail. The first limitation was that both schools were located in western Pennsylvania approximately 70 miles apart. The second limitation involved the distribution of the survey. The entire population at Thiel College was given the opportunity to take the survey, while only students in the School of Communications and Information Systems at Robert Morris University were invited to complete the survey. Due to variance between the sample sizes at the schools, 83 at one school and 302 at the other, this could impact some of the general conclusions as noted in RQ1.

\section{CONCLUDING REMARKS}

Conclusions of this exploratory research study found that over $80 \%$ of the population has purchased a smartphone. Additionally, the study explored multiple ways current college students use their phones, which differs from the traditional way phones were initially used. Furthermore, research indicated that the most popular apps are social networking and games. Additionally, students tend to only use their cellphones for apps and texting, while not fully utilizing the scope of smartphone functionality. However, students are still using their cellphones for communication and to stay in touch with each other. Students have discovered new ways of staying connected with their friends. The times of walking down the street to meet someone have diminished, because now students simply text their friends to communicate and, when friends are simply a click away, feel secure and safe, which is a basic human need. 


\section{Issues in Information Systems \\ Volume 17, Issue IV, pp. 8-20, 2016}

Overall, the results of this study should be used to inform the information systems community and individuals working in education because students' study habits are constantly changing now that the majority of students own a smartphone. Moreover, knowing how to use and integrate this technology can positively impact a college student's education. The current generation of users is considered iGeners, which means the children in classrooms today are tomorrow's work force and they are always "plugged-in" (Ferriter and Garry, 2010).

In summary, the key disadvantages to increased cellphone usage include: hindering classroom performance because college students are consistently on their smartphones, and ever increasing usage. The increased usage could possibly cause students to develop more problems along their education journeys, thus resulting in increasing dropout rates and fewer college graduates. Another disadvantage to increased smartphone use is the anxiety students experience because of their constant need to have their phone on them at all times. Finally, further disadvantages to a student using a phone in class include being both a distraction and an annoyance to fellow classmates and instructors, because of the lack of attention.

This study along with researcher observation found several advantages to increased cellphone usage, including the use of phones as teaching and learning tools to accommodate different learning styles. Additionally, students can simply utilize their smartphones and open an app to study notes for classes. Further added benefits to increased smartphone use for educational purposes include: not wasting paper, the ability to store information for a longer period of time, and access to the information at any time and place. The researcher's personal observation of students suggests that the majority of college students use their smartphones and apps for academic purposes within the classroom and educational context. The researcher suggests that college students should continue using smartphones to study if the devices help students earn better grades, potentially leading to a more positive outlook on life and, ultimately, achievement of the students' academic goals.

It is very apparent that iGeners are technologically savvy; however, the overall body of literature provides evidence that students use their cellphones with high frequency levels, and this frequent usage could cause educational problems. Further research should be conducted to determine if problems in education could arise due to increased smartphone use. However, in the researcher's observations and discussion with iGeners, a conclusion may be drawn that iGeners are inherently too busy to participate in additional surveys to eliminate the existing research gaps. Finally, in light of research gathered and analyzed, the researcher warns people to be aware when using communication technology such as e-mail/texting/messaging and social media. When sending e-mails, text messages, or posting to social media, users should monitor the typed words carefully and engage high levels of netiquette. One suggestion is to write an e-mail, save it as a draft, and then re-read and edit the e-mail later to ensure clarity. In regard to social media posts, the researcher suggests a similarly mindful approach: think before posting, remember being online brings a spotlight of visibility, everyone can read what is posted, and let your written words be filled with grace or encouraging thoughts to maximize every opportunity for positive interactions with others.

\section{REFERENCES}

Baker. (2012). On the use of cellphones and other electronic devices in the classroom: evidence from a survey of faculty and students. Retrieved from ERIC: http://eric.ed.gov/?id=EJ994147

Beaver, T. (2010, September). Hold The Phone!: Cellphone Use and Partner Reaction Among University Students. Retrieved from EBSCO host: http://connection.ebscohost.com/c/articles/54016496/hold-phone-cell-phoneuse-partner-reaction-among-university-students

Berger, E. (2013, December 16). Study: Stu-dents who use cellphones more get lower grades. Retrieved from Chron: http://blog.chron.com/sciguy/2013/12/study-students-who-use-cellphones-more-get-lower-grades/

Bowen, K. (2012, September 25). Student preferences for mobile app usage. Retrieved from Academia.edu: http://www.academia.edu/3138560/Student_Preferences_for_Mobile_App_Usage 
Chen, B. (2013, October 7). Exploring Students Mobile Learning Practices in Higher Education. Retrieved from EDUCAUSE Review online: http://www.educause.edu/ero/article/exploring-students-mobile-learningpractices-higher-education

eCycle Best. (2012). Smartphones as Tools for Education: Getting Smart With Smartphones. Retrieved from eCycle Best: http://www.ecyclebest.com/smartphone/articles/smartphones-as-tools-for-education

Elder. (2013, December). College student's cellphone use, beliefs, and effects on their learning. Retrieved from EBSCO host: http://web.a.ebscohost.com/abstract?direct=true \&profile=ehost\&scope $=$ site\&authtype $=$ crawler\&jrnl=0146 3934\&AN=93813987\&h=Qg8By9hfQ177DFKkZJDtuSFFj0Akb\%2fO7au1lLQgXZLAr3UvFrp9M7Fiim VSIMGnsBJNM2JqPQWHLGCVBNh2VJw\%3d\%3d\&crl=c

eMarketer. (2012, September 6). Apps are a leading product category purchased via mobile among college students. Retrieved from eMarketer: http://www.emarketer.com/Article/College-Students-Rely-on-AppsCommunicate/1009325

Epstein, J. (2013, October). Smartphone Applications in Clinical Practice. Retrieved from questia: http://www.questia.com/library/journal/1G1-348871975/smart-phone-applications-in-clinical-practice

Ferriter, W., \& Garry, A. (2010). Teaching the igeneration: 5 easy ways to introduce essential skills with web 2.0 tools. Moorabbin, Vic.: Hawker Brownlow Education.

Hamilton, M. (2013, July 15). Frequent smartphone use linked to poor fitness. Retrieved from nbc news: http://www.nbcnews.com/health/diet-fitness/frequent-smart-phone-use-linked-poor-fitness-f6C10642276

Hingorani. (n.d.). Exploring How Smartphones Supports Students Lives. Retrieved from Issues in Information Systems: http://iacis.org/iis/2012/83_iis_2012_33-40.pdf

Jesse, G. (2013). Like, Tweet, Or Pin: College Students and Their Current Use Of Social Media. Issues in Information Systems, 14(1), 403-414.

Russell, K. (2014). Fitness App Usage Is Growing 87\% Faster Than The Overall App Market. Retrieved July 24, 2015, from http://techcrunch.com/2014/06/19/fitness-app-usage-is-growing-87-faster-than-the-overall-appmarket/

Laird, S. (2012, June 30). In a Relationship: College Students and Their Smartphones. Retrieved March 2014, 2014, from Mashable: http://www.huffingtonpost.com/2010/06/28/998-of-college-students-h_n_628161.html

Martin, C. (n.d.). Cellphone Use and Concentration During Class. Retrieved from Whittemore School: http://www.unh.edu/news/docs/2010CellphoneUsageStudy.pdf

Nahorniak, M. (2012, July 6). Mobile Media: How Do College Students Use Mobile Phones? Retrieved March 21, 2015, from http://www.socialmediatoday.com/content/mobile-media-how-do-college-students-use-mobilephones

Peterson, D. (2011, November 10). Stats on College Students \& their cellphones. Retrieved March 15, 2014, from Generation Mobile: http://thedrewpeterson.com/2011/11/10/stats-on-college-students-their-cell-phones/

Post, H. (2011, May 25). 99.8\% of college students have cellphones: Ball State Study. Retrieved March 15, 2014, from Huff Post: http://www.huffingtonpost.com/2010/06/28/998-of-college-students-h_n_628161.html 


\section{Issues in Information Systems \\ Volume 17, Issue IV, pp. 8-20, 2016}

Smith, B. (2013, December 6). Study: Cell-phone Use Leads To Lower GPA, More Stress And Anxiety. Retrieved from redOr-bit: http://www.redorbit.com/news/health/1113022165/college-student-cell-phone-smartphoneuse-lower-gpa-higher-anxiety-stress-levels-120613/

Tally, S. (2012, September 25). Students prefer apps to the Web when using smartphones. Retrieved from Purdue News: http://www.purdue.edu/newsroom/releases/2012/Q3/students-prefer-apps-to-the-web-when-usingsmartphones.html

Thomas, B. (2013, August 12). Kent State Study Looks at Cellphone Use and Fitness in College Students. Retrieved from Kent State University: http://www.kent.edu/news/announcements/success/cell-phoneuse.cfm.

Tulane, S. (2010). Perceptions of Texting: A Comparison of Female High School and College Students. Retrieved from Questia: http://www.questia.com/library/journal/1G1-331348554/perceptions-of-texting-acomparison-of-female-high

Weimer, M. (2014, January 8). The Age of Dis-traction: Getting Students to Put Away Their Phones and Focus on Learning. Retrieved from Faculty Focus: http://www.facultyfocus.com/articles/teaching-professor-blog/theage-of-distraction-getting-students-to-put-away-their-phones-and-focus-on-learning/ 


\section{APPENDIX A}

Table 1. RQ1: Preferred Operating System

\begin{tabular}{|c|c|c|c|}
\hline Q18: What operating system (O.S.) is on your Smartphone? & $\begin{array}{c}\text { TC } \\
(\mathrm{N}=219)\end{array}$ & $\begin{array}{c}\text { RMU } \\
(\mathrm{N}=83)\end{array}$ & $\begin{array}{c}\text { Average } \\
(\mathrm{N}=302)\end{array}$ \\
\hline Android & $47.10 \%$ & $57.80 \%$ & $52.45 \%$ \\
\hline Apple & 52.90 & $42.20 \%$ & $47.55 \%$ \\
\hline
\end{tabular}

Table 2. RQ2: Number of apps installed on cellphone

\begin{tabular}{|c|l|l|l|}
\hline $\begin{array}{l}\text { Q19: About how many apps do you currently have on your } \\
\text { smartphone? }\end{array}$ & $\begin{array}{c}\text { TC } \\
(\mathrm{N}=214)\end{array}$ & $\begin{array}{c}\text { RMU } \\
(\mathrm{N}=81)\end{array}$ & $\begin{array}{l}\text { Average } \\
(\mathrm{N}=295)\end{array}$ \\
\hline Average & 27 & 33 & 30 \\
\hline Median & 20 & 30 & 25 \\
\hline
\end{tabular}

Table 3. RQ3: Most useful app

\begin{tabular}{|l|c|c|c|}
\hline Q20: Which types of apps are most useful to you? & $\begin{array}{c}\text { TC } \\
(\mathrm{N}=218)\end{array}$ & $\begin{array}{c}\text { RMU } \\
(\mathrm{N}=84)\end{array}$ & $\begin{array}{c}\text { Average } \\
(\mathrm{N}=302)\end{array}$ \\
\hline Utility apps (calculate, convert, translate, etc.) & $73 \%$ & $75.00 \%$ & $74.20 \%$ \\
\hline $\begin{array}{l}\text { Social networking apps (location check-ins, friend status } \\
\text { updates, etc.) }\end{array}$ & $79 \%$ & $67.90 \%$ & $73.65 \%$ \\
\hline Weather apps (local forecasts, natural disaster updates, etc.) & $69 \%$ & $70.20 \%$ & $69.75 \%$ \\
\hline Game apps (puzzles, charades, etc.) & $67 \%$ & $52.40 \%$ & $59.70 \%$ \\
\hline Productivity apps (calendar, to do list, price checker, etc.) & $51 \%$ & $61.90 \%$ & $56.20 \%$ \\
\hline Search tool apps (directions, phone numbers, recipes, etc.) & $45 \%$ & $46.40 \%$ & $45.90 \%$ \\
\hline Sports apps (sports schedules, scores, headlines, etc.) & $40 \%$ & $39.30 \%$ & $39.60 \%$ \\
\hline $\begin{array}{l}\text { Entertainment apps (movie trailers, celebrity gossip, radio } \\
\text { station guides, etc.) }\end{array}$ & $36 \%$ & $41.70 \%$ & $38.75 \%$ \\
\hline $\begin{array}{l}\text { News apps (local news, national headlines, technology } \\
\text { announcements, etc.) }\end{array}$ & $30 \%$ & $40.50 \%$ & $35.15 \%$ \\
\hline $\begin{array}{l}\text { Travel apps (airplane tickets, tourist guides, public } \\
\text { transportation info, etc.) }\end{array}$ & $12 \%$ & $11.90 \%$ & $11.90 \%$ \\
\hline
\end{tabular}

Table 4. RQ4: Least useful app

\begin{tabular}{|l|c|c|c|}
\hline Q21: Which types of apps are least useful to you? & $\begin{array}{c}\text { TC } \\
(\mathrm{N}=209)\end{array}$ & $\begin{array}{c}\text { RMU } \\
(\mathrm{N}=75)\end{array}$ & $\begin{array}{c}\text { Average } \\
(\mathrm{N}=284)\end{array}$ \\
\hline $\begin{array}{l}\text { Travel apps (airplane tickets, tourist guides, public } \\
\text { transportation info, etc.) }\end{array}$ & $58.70 \%$ & $56.00 \%$ & $57.35 \%$ \\
\hline Sports apps (sports schedules, scores, headlines, etc.) & $49.30 \%$ & $32.50 \%$ & $40.90 \%$ \\
\hline $\begin{array}{l}\text { Entertainment apps (movie trailers, celebrity gossip, radio } \\
\text { station guides, etc.) }\end{array}$ & $33.30 \%$ & $39.70 \%$ & $36.50 \%$ \\
\hline $\begin{array}{l}\text { News apps (local news, national headlines, technology } \\
\text { announcements, etc.) }\end{array}$ & $24.00 \%$ & $34.00 \%$ & $29.00 \%$ \\
\hline Game apps (puzzles, charades, etc.) & $26.70 \%$ & $23.90 \%$ & $25.30 \%$ \\
\hline Search tool apps (directions, phone numbers, recipes, etc.) & $16.00 \%$ & $12.40 \%$ & $14.20 \%$ \\
\hline $\begin{array}{l}\text { Social networking apps (location check-ins, friend status } \\
\text { updates, etc.) }\end{array}$ & $17.30 \%$ & $11.00 \%$ & $14.15 \%$ \\
\hline Productivity apps (calendar, to do list, price checker, etc.) & $9.30 \%$ & $15.80 \%$ & $12.55 \%$ \\
\hline Weather apps (local forecasts, natural disaster updates, etc.) & $9.30 \%$ & $6.70 \%$ & $8.00 \%$ \\
\hline Utility apps (calculate, convert, translate, etc.) & $5.30 \%$ & $9.10 \%$ & $7.20 \%$ \\
\hline
\end{tabular}


Table 5. RQ5: App most frequently used

\begin{tabular}{|c|c|c|c|}
\hline $\begin{array}{l}\text { Q22: What is the name of the app you use the most on your } \\
\text { smartphone? }\end{array}$ & $\begin{array}{c}\text { TC } \\
(\mathrm{N}=207)\end{array}$ & $\begin{array}{l}\text { RMU } \\
(\mathrm{N}=80)\end{array}$ & $\begin{array}{c}\text { Average } \\
(\mathrm{N}=287)\end{array}$ \\
\hline Social Media (Twitter, Facebook, Instagram, Pinterest) & $57.00 \%$ & $37.50 \%$ & $47.25 \%$ \\
\hline Mail \& Messaging & $2.90 \%$ & $26.25 \%$ & $14.57 \%$ \\
\hline Web Browser & $4.35 \%$ & $7.50 \%$ & $5.92 \%$ \\
\hline Games & $7.25 \%$ & $3.75 \%$ & $5.50 \%$ \\
\hline Music Apps & $4.83 \%$ & $6.25 \%$ & $5.54 \%$ \\
\hline $\begin{array}{l}\text { System } \\
\text { (Calendar, Alarm, Notes, E-mail, Camera, maps, flashlight) }\end{array}$ & $5.80 \%$ & $3.75 \%$ & $4.77 \%$ \\
\hline Sports & $2.90 \%$ & $5.00 \%$ & $3.95 \%$ \\
\hline Weather & $5.31 \%$ & $1.25 \%$ & $3.28 \%$ \\
\hline Miscellaneous Apps (App mentioned only one time) & $5.31 \%$ & $1.25 \%$ & $3.28 \%$ \\
\hline Nutrition/Health & $1.93 \%$ & $2.50 \%$ & $2.22 \%$ \\
\hline Reading apps & $1.45 \%$ & $2.50 \%$ & $1.97 \%$ \\
\hline News & $0.97 \%$ & $2.50 \%$ & $1.73 \%$ \\
\hline
\end{tabular}

Table 6. RQ6: App most frequently used

\begin{tabular}{|l|r|r|c|}
\hline $\begin{array}{l}\text { Q23: How often do you enter into/use your primary app in a } \\
\text { day on your smartphone? }\end{array}$ & \multicolumn{1}{c|}{$\begin{array}{c}\text { TC } \\
(\mathrm{N}=200)\end{array}$} & $\begin{array}{c}\text { RMU } \\
(\mathrm{N}=80)\end{array}$ & $\begin{array}{c}\text { Average } \\
(\mathrm{N}=280)\end{array}$ \\
\hline Average & 11.50 & 9.99 & 10.74 \\
\hline Median & 6.00 & 6.00 & 6.00 \\
\hline
\end{tabular}

Table 7. RQ7: Primary Social Media App

\begin{tabular}{|l|r|r|r|}
\hline $\begin{array}{l}\text { Q24: Select ALL that apply. Which of the following Social } \\
\text { Media Apps do you use on your smartphone? }\end{array}$ & $\begin{array}{c}\text { TC } \\
(\mathrm{N}=218)\end{array}$ & \multicolumn{1}{c|}{$\begin{array}{c}\text { RMU } \\
(\mathrm{N}=84)\end{array}$} & $\begin{array}{c}\text { Average } \\
(\mathrm{N}=302)\end{array}$ \\
\hline Facebook & $81.00 \%$ & $84.90 \%$ & $82.95 \%$ \\
\hline Twitter & $54.80 \%$ & $69.70 \%$ & $62.25 \%$ \\
\hline Pinterest & $26.20 \%$ & $32.10 \%$ & $29.15 \%$ \\
\hline None & $14.30 \%$ & $5.50 \%$ & $9.90 \%$ \\
\hline Other & $81.00 \%$ & $84.90 \%$ & $82.95 \%$ \\
\hline
\end{tabular}

Participation Statistics for Thiel College (TC) and Robert Morris University (RMU)

\begin{tabular}{|c|c|c|c|}
\hline & $\begin{array}{c}\text { TC } \\
\text { (Entire Population) }\end{array}$ & $\begin{array}{c}\text { RMU } \\
\text { (School of C \& I.S.) }\end{array}$ & $\begin{array}{c}\text { Average } \\
\text { Participation }\end{array}$ \\
\hline Total Enrollment & 981 & 931 & 1912 \\
\hline Consent Agreement \& $>18$ years old & 291 & 104 & 395 \\
\hline Percent of population surveyed & $30 \%$ & $11 \%$ & $21 \%$ \\
\hline
\end{tabular}

Demographic Statistics for Thiel College (TC) and Robert Morris University (RMU)

\begin{tabular}{|c|c|c|c|c|c|c|c|c|}
\hline Age & $\mathbf{T C}$ & RMU & Gender & TC & RMU & GPA & TC & RMU \\
\hline 18 & $17.2 \%$ & $6.8 \%$ & Male & $40.1 \%$ & $64.7 \%$ & $\mathrm{~A}(4.0 \&>)$ & $17.1 \%$ & $28.2 \%$ \\
\hline 19 & $27.0 \%$ & $15.5 \%$ & Female & $59.2 \%$ & $35.3 \%$ & $\mathrm{~A} / \mathrm{B}(3.5)$ & $27.2 \%$ & $40.8 \%$ \\
\hline 20 & $26.0 \%$ & $17.5 \%$ & & & & $\mathrm{~B}(3.0)$ & $28.9 \%$ & $22.3 \%$ \\
\hline 21 & $16.6 \%$ & $18.4 \%$ & Race & TC & RMU & $\mathrm{B} / \mathrm{C}(2.5)$ & $21.3 \%$ & $8.7 \%$ \\
\hline 22 & $8.8 \%$ & $6.8 \%$ & White, Caucasian & $85.9 \%$ & $91.2 \%$ & $\mathrm{C}(2.0)$ & $2.4 \%$ & $0.0 \%$ \\
\hline 23 & $0.3 \%$ & $3.9 \%$ & White, non-Hispanic & $2.8 \%$ & $1.0 \%$ & $\mathrm{C} / \mathrm{D}(1.5)$ & $1.4 \%$ & $0.0 \%$ \\
\hline 24 & $0.3 \%$ & $1.0 \%$ & African-American & $6.0 \%$ & $5.9 \%$ & $\mathrm{D}(1.0)$ & $0.3 \%$ & $0.0 \%$ \\
\hline $25-30$ & $0.3 \%$ & $15.5 \%$ & Hispanic & $2.5 \%$ & $0.0 \%$ & Don't know & $0.7 \%$ & $0.0 \%$ \\
\hline 30 & $2.4 \%$ & $14.6 \%$ & Asian-Pacific Islander & $0.4 \%$ & $1.0 \%$ & & & \\
\hline
\end{tabular}

